\title{
Synthesis, Characterization and Antimicrobial Screening of New Schiff Bases Linked to Phthalimidyl Phenyl Sulfonate Moiety
}

\author{
Ahlam M. Al-Azzawi*
}

Marwa S. Abd Al-Razzak*

Received 20, December, 2012

Accepted 5, February, 2014

\begin{abstract}
A series of Schiff bases linked to phthalimidyl phenyl sulfonate moiety have been synthesized via multistep synthesis.

The first step involved reaction of phthalic anhydride with aniline producing N-phenyl phthalamic acid which was subsequently dehydrated to the corresponding N-phenyl phthalimide via treatment with acetic anhydride and anhydrous sodium acetate. The synthesized imide was treated with chlorosulfonic acid in the third step producing 4-(N-phthalimidyl) phenyl sulfonyl chloride which was introduced in reaction with 4-hydroxy acetophenone in the fourth step producing 4-[4-( $\mathrm{N}-$ phthalimidyl) phenyl sulfonate] acetophenone and this in turn was introduced successfully in condensation reaction with various aromatic primary amines affording the desired new Schiff bases. The newly synthesized compounds were characterized through spectral data including FTIR, ${ }^{1} \mathrm{HNMR}$ and ${ }^{13} \mathrm{CNMR}$. Antimicrobial activity of the prepared Schiff bases was evaluated against two types of bacteria and one type of fungi and the new Schiff bases were found to exhibit good antimicrobial activity against the tested organisms.
\end{abstract}

Key words: phthalimide, phthalimidyl phenyl sulfonyl chloride, phthalimidyl phenyl sulfonate

\section{Introduction:}

Schiff bases are important intermediates for the synthesis of some bioactive compounds such as $\beta$ lactams, and they form a significant class of compounds in medicinal and pharmaceutical chemistry with a variety of interesting biological actions including antibacterial, antifungal, antimouse hepatitis virus (MHV), and adenovirus type 5 (Ad 5), anticancer and herbicidal activities[1-5].

Similarly phthalimides which are bicyclic non-aromatic nitrogen heterocycles are important compounds with a variety of applications and a wide range of properties [6-8]. Generally they are used as starting materials and intermediates for the

synthesis of many types of alkaloids and pharmacophores, synthesis of pesticides and lately are being under intense biomedical research due to their important biological effects [912]. In light of the interesting variety of biological activities seen in compounds containing phthalimidies and azomethine linkages it was thought of interest to examine the effect of having these two functionalities present simultaneously in one structure.

Based on this notion we decide to synthesize several new Schiff bases linked to phthalimidyl sulfonate moiety and to test them against types of bacteria and fungi.

*Department of Chemistry, College of Science, University of Baghdad 


\section{Material and Methods:}

Melting points were determined on Thomas Hoover apparatus and were uncorrected. FTIR spectra were recorded on SHIMADZU FTIR-8400 Fourier Transform Infrared spectrophotometer. ${ }^{1} \mathrm{H}-\mathrm{NMR}$ and ${ }^{13} \mathrm{C}-$ NMR spectra were recorded on Bruker $300 \mathrm{MHz}$ instrument in Al-Albate University in Jordan using tetramethylsilane (TMS) as an internal standard and DMSO- $\mathrm{d}_{6}$ as a solvent.

\section{1- Preparation of $\mathrm{N}$ -} phenylphthalamic Acid (1)

To a solution of $(0.01 \mathrm{~mol}, 1.48 \mathrm{~g})$ phthalic anhydride in $(25 \mathrm{~mL})$ of acetone, $(0.01 \mathrm{~mol}, 1 \mathrm{~mL})$ of aniline was added dropwise with continuous stirring under cooling conditions [13], then was stirred for two hours at room temperature. The resulted precipitate was filtered, dried then purified by recrystallization from ethanol.

\section{2- Preparation of N-phenyl phthalimide (2)}

A mixture of $(0.01 \mathrm{~mol}, 2.41 \mathrm{~g})$ of $\mathrm{N}$-phenyl phthalamic acid in $(25 \mathrm{~mL})$ of acetic anhydride and (5\%) by weight of anhydrous sodium acetate was refluxed for two hours with stirring [14].

The resulted homogenous solution was cooled to room temperature then poured into crushed ice with stirring and the obtained precipitate was filtered, dried and recrystallized from acetone.

\section{3- Preparation of 4-(N- phthalimidyl) phenyl sulfonyl chloride (3)}

Chlorosulfonic acid $(4 \mathrm{ml})$ was added dropwise to $(0.01 \mathrm{~mol}, 2.23 \mathrm{~g})$ of $\mathrm{N}$-phenylphthalimide during two hours with stirring and keeping temperature at zero ${ }^{\circ} \mathrm{C}$ [14].
Stirring was continued for ten hours at room temperature then the resulted mixture was poured into crushed ice carefully with stirring. The obtained precipitate was filtered, dried then recrystallized from acetone.

\section{4- Preparation of 4-[4-(N- phthalimidyl) phenyl sulfonate]acetophenone (4)}

In a three necked flask equipped with a stirrer and a thermometer a mixture of $(0.015 \mathrm{~mol}, 2.04 \mathrm{~g})$ of $4-$ hydroxy acetophenone and $(3 \mathrm{~mL})$ of pyridine was placed. The flask was surrounded by a bath sufficiently cold to lower the mixture temperature to $10^{\circ} \mathrm{C}$ then 4 -(N-phthalimidyl)phenyl sulfonyl chloride $(0.01 \mathrm{~mol}, 3.22 \mathrm{~g})$ was added in portions during twenty minutes with continuous stirring [15].

The resulted mixture was refluxed for two hours on a water bath then poured into cold water with stirring until the resulted oily layer solidified. The solid product was filtered, washed with water, dried then recrystallized from ethanol. Physical properties of compounds $(1,2,3,4)$ are listed in Table (1).

\section{5- Preparation of 4-[4 - $(\mathrm{N}-$ phthalimidyl) phenyl sulfonate] methyl benzylidene (5-11)}

In a suitable round bottomed flask (0.01 mol, $4.21 \mathrm{~g}$ ) of compound (4) 4[4-(N-phthalimidyl) phenyl sulfonate] acetophenone was dissolved in (20 $\mathrm{mL})$ of absolute ethanol then $(0.01$ mol) of primary aromatic amine was added followed by addition of (2-3) drops of glacial acetic acid with stirring [2]. The mixture was refluxed for four hours then cooled to room temperature and the obtained precipitate was filtered, dried and purified by recrystallization from a suitable solvent. Physical properties of 
compounds (5-11) are listed in Table (2).

\section{6- Biological study}

The cup plate method using nutrient agar medium was employed in studying the antimicrobial activity of the prepared Schiff bases [14]. DMF was used as sample solution and sample size for all compounds was fixed at $(0.1 \mathrm{~mL})$. Using a sterilized cork borer cups were scooped out of agar medium contained in a petridish which was previously inoculated with the microorganisms. The tested compound solution $(0.1 \mathrm{~mL})$ was added in the cups and the petridishes were subsequently incubated at $37^{\circ} \mathrm{C}$ for $48 \mathrm{hrs}$. Zones of inhibition produced by each compound was measured in $\mathrm{mm}$ and the results are listed in Table (5).

\section{Results and Discussion}

Since both phthalimides and Schiff bases belong to a widely used group intermediates important for production of many types of pharmaceuticals and have wide spectrum of biological applications the target of the present work has been directed towards building of new molecules containing these two active moieties. Thus the newly synthesized compounds containing both phthalimide and Schiff base moieties linked together through phenyl sulfonate component. Performing this target was made via multistep synthesis which described in Scheme (1).

The first step involved preparation of N-phenyl phthaliamic acid via reaction of equimolar amounts of phthalic anhydride and aniline in acetone. Dehydration of compound (1) using acetic anhydride and anhydrous sodium acetate in the second step afforded compound (2) N-phenyl phthalimide.

In the third step the prepared imide (2) was introduced in chlorosulfonation reaction via treatment with chlorosulfonic acid producing compound (3) which in turn was introduced in the fourth step in esterification reaction with 4-hydroxy acetophenone producing compound (4). In the final step of this work the prepared new ketone (phthalimidyl phenyl sulfonate acetophenone) (4) was introduced in condensation reaction with different primary aromatic amines producing the desired target Schiff bases (5-11). 
<smiles>CC(C(=O)O)c1ccccc1C(=O)Nc1ccccc1</smiles>

(1) $\mathrm{N}$-phenyl phthalamic acid

(2)<smiles>CC(=O)ONCc1ccccc1Cl</smiles>
$\mathrm{N}$-phenyl phthalimide (3)<smiles>CON(OC(C)c1ccccc1C)c1ccc(S(=O)(=O)Cl)cc1</smiles>

step (1)

step (2)

step (3)

N-(4-phthalimidyl) phenyl sulfonyl chloride

(4)

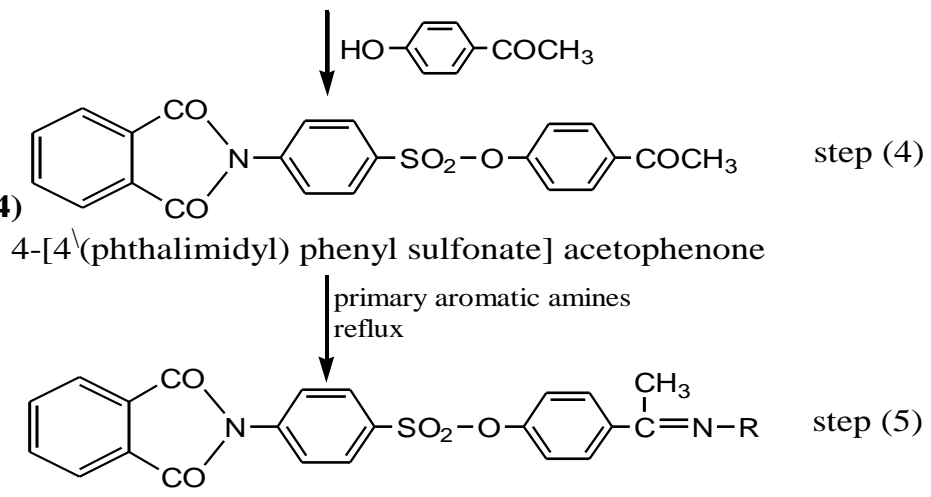

(5-11)

Schiff bases

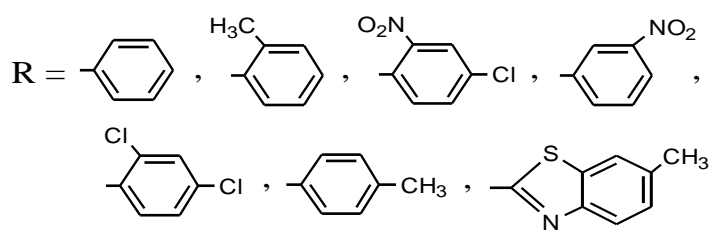

Scheme (1)

The strategy which we depend on in building the new Schiff bases involved introducing of sulfonyl chloride group in para position of phenyl ring attached to phthalimide moiety then this compound which represents acid chloride introduced in esterification reaction in which nucleophilic replacement of chloride with p-acetophenoxide moiety was performed and by this step the resulted new compound (4) contain carbonyl group which was ready for nucleophilic attack by amines during condensation reaction in the final step affording the desired Schiff bases. Structures of prepared compounds were confirmed by FTIR, ${ }^{1}$ HNMR and ${ }^{13}$ CNMR spectral data.

FTIR spectrum of compound (1) showed strong absorption bands at 3325 and $3136 \mathrm{~cm}^{-1}$ due to $v(\mathrm{O}-\mathrm{H})$ carboxylic and $v(\mathrm{~N}-\mathrm{H})$ amide. Other absorptions appeared at $1720 \mathrm{~cm}^{-1}$, 
$1643 \mathrm{~cm}^{-1}$ and $1600 \mathrm{~cm}^{-1}$ due to $v(\mathrm{C}=\mathrm{O})$ carboxylic, $v(\mathrm{C}=\mathrm{O})$ amide and $v(\mathrm{C}=\mathrm{C})$ aromatic respectively ${ }^{(17)}$. FTIR spectrum of compound (2) showed disappearance of $v(\mathrm{O}-\mathrm{H})$ and $v(\mathrm{~N}-\mathrm{H})$ absorption bands proving success of dehydration reaction and appearance of two bands at $1735 \mathrm{~cm}^{-1}$ and $1708 \mathrm{~cm}^{-1}$ due to asym. and sym., bands of $v(\mathrm{C}=\mathrm{O})$ imide. FTIR spectrum of compound (3) showed two clear bands at $1365 \mathrm{~cm}^{-1}$ and $1188 \mathrm{~cm}^{-1}$ due to $v\left(\mathrm{SO}_{2}\right)$ asym. and $v\left(\mathrm{SO}_{2}\right)$ sym. respectively indicating success of introducing sulfonyl chloride moiety in phenyl phthalimide molecule. FTIR spectrum of compound (4) showed absorption bands at $1739 \mathrm{~cm}^{-1}$ and 1720 $\mathrm{cm}^{-1}$ due to asym. and sym. $v(\mathrm{C}=\mathrm{O})$ imide. The appearance of new band at $1674 \mathrm{~cm}^{-1}$ belong to $v(\mathrm{C}=\mathrm{O})$ ketone is a good proof for success of compound (4) formation [17].

Other bands appeared at $1593 \mathrm{~cm}^{-1}$ , $1361 \mathrm{~cm}^{-1}$ and $1176 \mathrm{~cm}^{-1}$ due to $v(\mathrm{C}=\mathrm{C})$ aromatic, asym. and sym. $v\left(\mathrm{SO}_{2}\right)$ respectively. Finally FTIR spectra of the new Schiff bases (5-11) showed disappearance of absorption band at $1674 \mathrm{~cm}^{-1}$ belong to $v(\mathrm{C}=\mathrm{O})$ ketone and appearance of clear strong absorption band at (1681-1690) $\mathrm{cm}^{-1}$ due to $v(\mathrm{C}=\mathrm{N})$ imine.

Other absorption bands in FTIR spectra of compounds (5-11) are shown at (1725-1743) $\mathrm{cm}^{-1}$, (17101726) $\mathrm{cm}^{-1}$, (1593-1595) $\mathrm{cm}^{-1}$, (1361$1385) \mathrm{cm}^{-1}$ and (1176-1199) $\mathrm{cm}^{-1}$ due to asym. $v(\mathrm{C}=\mathrm{O})$ imide, sym. $v(\mathrm{C}=\mathrm{O})$ imide, $v(\mathrm{C}=\mathrm{C})$ aromatic, asym. and sym. $v\left(\mathrm{SO}_{2}\right)$ respectively. All details of FTIR spectral data of compounds (1-4) and (5-11) are listed in Table (3) and (4).

${ }^{1} \mathrm{H}-\mathrm{NMR}$ spectrum of compound (1) showed signals at $\delta=(7.04-7.89)$ ppm belong to aromatic protons and $(\mathrm{N}-\mathrm{H})$ proton and a clear signal at $\delta=$ $10.33 \mathrm{ppm}$ due to $(\mathrm{O}-\mathrm{H})$ carboxylic proton [17], while ${ }^{13} \mathrm{C}-\mathrm{NMR}$ spectrum of this compound showed signals at $\delta=$ (119.9-140), 167.8 and $167.92 \mathrm{ppm}$ due to aromatic carbons, $(\mathrm{C}=\mathrm{O})$ amide and $(\mathrm{C}=\mathrm{O})$ carboxyl respectively.

${ }^{1} \mathrm{H}-\mathrm{NMR}$ spectrum of compound (2) showed disappearance of $(\mathrm{OH})$ carboxyl proton signal and appearance of two multiplet signals at $\delta=(7.44$ 7.56) and (7.89-7.97) ppm belong to protons of two aromatic rings. ${ }^{13} \mathrm{C}$ NMR spectrum of compound (2) showed signals at $\delta=(123.8-135.1)$ ppm and at $\delta=167.4 \mathrm{ppm}$ belong to aromatic and $(\mathrm{C}=\mathrm{O})$ imide respectively. ${ }^{1} \mathrm{H}-\mathrm{NMR}$ of compound (4) showed signals at $\delta=2.56$ and $\delta=$ (7.28-8.13) ppm due to $\left(\mathrm{CH}_{3}\right)$ group protons and aromatic ring protons, while ${ }^{13} \mathrm{C}$-NMR spectrum of this compound showed signals at $\delta=27.2$, (122.6-153), 166.8 and $198 \mathrm{ppm}$ belong to $\mathrm{CH}_{3}$ group, aromatic ring carbons, $(\mathrm{C}=\mathrm{O})$ imide and $(\mathrm{C}=\mathrm{O})$ ketone respectively.

${ }^{1} \mathrm{H}-\mathrm{NMR}$ spectrum of Schiff base (6) showed two signals at $\delta=2.35$ and $2.56 \mathrm{ppm}$ due to two $\left(\mathrm{CH}_{3}\right)$ groups and signals at $\delta=(7.28-8.12) \mathrm{ppm}$ due to aromatic protons. ${ }^{13} \mathrm{C}$-NMR spectrum of the same compound (6) showed signals at $\delta=27.21$, (122.5-138.2), 152.6 and $166.8 \mathrm{ppm}$ belong to $\mathrm{CH}_{3}$ groups, aromatic rings cabons, $(\mathrm{C}=\mathrm{N})$ imine and $(\mathrm{C}=\mathrm{O})$ imide. Finally ${ }^{1} \mathrm{H}$ NMR spectrum of Schiff base (9) showed signals at $\delta=2.54,2.56 \mathrm{ppm}$ due to two $\left(\mathrm{CH}_{3}\right)$ groups, signals at $\delta=$ (7.1-8) ppm are due to aromatic protons while ${ }^{13} \mathrm{C}$-NMR of the same compound (9) showed signals at $\delta=$ 27.2, (122-135), 153 and $168 \mathrm{ppm}$ belong to $\mathrm{CH}_{3}$ groups, aromatic ring carbons, $(\mathrm{C}=\mathrm{N})$ imine and $(\mathrm{C}=\mathrm{O})$ imide respectively.

\section{Biological Activity}

The synthesized imides in this work were expected to possess 
biological activity since they have two active moieties in their molecules thus a prileminary evaluation of antibacterial activity of the new Schiff bases were tested against two types of bacteria Staphylococcus aureus (Gram positive) and Escherichia Coli (Gram negative).

Antifungal activity of the new Schiff bases against Candida albicans fungi were tested also and the results which are listed in Table (5) indicated that compound (11) showed very high activity against $S$. aureus, compounds $(5,6,9)$ showed high activity while compounds $(7,8,10)$ showed moderate activity against this bacteria. On the other hand compound (11) showed very high activity and compounds (5, $7,8,10)$ showed high activity against E. Coli while compounds $(6,9)$ showed moderate activity against this bacteria. Finally compound (11) showed high activity against Candida albicans fungi, compounds $(5,7,10)$ showed moderate activity and compounds $(6,8,9)$ showed slight activity against this fungi.

\section{Conclusion:}

The presence of the two active functionalities phthalimide and Schiff base in the new synthesized molecules exhibit them biological activity and this activity was affected by type of substituents present in the molecules, thus the presence of the known biologically active benzothiazole moiety in compound (11) increased the activity of this compound among the others.

Table (1): Physical properties of prepared compounds (1-4)

\begin{tabular}{|c|c|c|c|c|c|}
\hline $\begin{array}{c}\text { Comp. } \\
\text { No. }\end{array}$ & Compound structure & color & $\begin{array}{c}\text { Melting } \\
\text { points } \\
{ }^{\circ} \mathbf{C}\end{array}$ & $\begin{array}{c}\text { Yield } \\
\%\end{array}$ & $\begin{array}{c}\text { Solvent of } \\
\text { recrystallization }\end{array}$ \\
\hline 1 & & White & $170-172$ & 88 & Ethanol \\
\hline 2 & & $\begin{array}{c}\text { Off } \\
\text { white }\end{array}$ & $204-205$ & 85 & Acetone \\
\hline 3 &
\end{tabular}

Table (2): Physical properties of prepared compounds (5-11)

\begin{tabular}{|c|c|c|c|c|c|}
\hline $\begin{array}{c}\text { Com } \\
\text { p. No. }\end{array}$ & Compound structure & $\begin{array}{c}\text { Meltin } \\
\mathbf{g} \\
\text { points } \\
{ }^{\circ} \mathbf{C}\end{array}$ & $\begin{array}{c}\text { Yiel } \\
\mathbf{d} \%\end{array}$ & $\begin{array}{c}\text { Solvent of } \\
\text { recrystallizati } \\
\text { on }\end{array}$ \\
\hline 6 & Color \\
\hline 7
\end{tabular}




\begin{tabular}{|c|c|c|c|c|c|}
\hline $\begin{array}{c}\text { Comp. } \\
\text { No. }\end{array}$ & Compound structure & Color & $\begin{array}{c}\text { Melting } \\
\text { points } \\
{ }^{\circ} \mathrm{C}\end{array}$ & $\begin{array}{c}\text { Yield } \\
\%\end{array}$ & $\begin{array}{c}\text { Solvent of } \\
\text { recrystallization }\end{array}$ \\
\hline 8 & & $\begin{array}{l}\text { Pale } \\
\text { brown }\end{array}$ & $172-173$ & 90 & Ethanol \\
\hline 9 & & $\begin{array}{c}\text { Off } \\
\text { white }\end{array}$ & $163-164$ & 63 & Ethanol \\
\hline 10 & & $\begin{array}{l}\text { Pale } \\
\text { yellow }\end{array}$ & $180-182$ & 85 & Acetone \\
\hline 11 & & $\begin{array}{c}\text { Pale } \\
\text { chlown }\end{array}$ & $167-168$ & 77 & Cyclohexane \\
\hline
\end{tabular}

Table (3): FTIR spectral data of compounds (1-4)

\begin{tabular}{|c|c|c|c|c|c|c|c|c|c|}
\hline \multirow[b]{2}{*}{$\begin{array}{c}\text { Comp. } \\
\text { No. }\end{array}$} & \multicolumn{9}{|c|}{ FTIR spectral data $\mathrm{cm}^{-1}$} \\
\hline & $\begin{array}{c}v(\mathrm{O}-\mathrm{H}) \\
\text { carboxylic }\end{array}$ & \multicolumn{2}{|c|}{$\begin{array}{c}v(\mathrm{~N}-\mathrm{H}) \\
\text { amide }\end{array}$} & \multicolumn{2}{|c|}{$\begin{array}{c}v(\mathrm{C}-\mathrm{H}) \\
\text { aromatic }\end{array}$} & \multicolumn{2}{|c|}{$\begin{array}{c}\mathrm{v}(\mathrm{C}=\mathrm{O}) \\
\text { carboxlyic }\end{array}$} & $\begin{array}{c}v(C=O) \\
\text { amide }\end{array}$ & $\begin{array}{c}v(\mathrm{C}=\mathrm{C}) \\
\text { aromatic }\end{array}$ \\
\hline 1 & 3325 & \multicolumn{2}{|r|}{3136} & \multicolumn{2}{|c|}{3062} & \multicolumn{2}{|c|}{1720} & 1643 & 1600 \\
\hline $\begin{array}{c}\text { Comp. } \\
\text { No. }\end{array}$ & \multicolumn{2}{|c|}{$v(\mathrm{C}-\mathrm{H})$ aromatic } & \multicolumn{3}{|c|}{$v(C=0)$ imide } & \multicolumn{3}{|c|}{$v(\mathrm{C}=\mathrm{C})$ aromatic } & $v(C-N)$ imide \\
\hline 2 & \multicolumn{2}{|l|}{3074} & \multicolumn{3}{|c|}{$\begin{array}{l}1735 \\
1708 \\
\end{array}$} & \multicolumn{3}{|c|}{1593} & 1384 \\
\hline $\begin{array}{l}\text { Comp. } \\
\text { No. }\end{array}$ & $\begin{array}{c}\nu(\mathrm{C}-\mathrm{H}) \\
\text { aromatic }\end{array}$ & \multicolumn{2}{|c|}{$\begin{array}{l}v(\mathrm{C}=\mathrm{O}) \\
\text { imide }\end{array}$} & \multicolumn{2}{|c|}{$\begin{array}{c}v(\mathrm{C}=\mathrm{C}) \\
\text { aromatic }\end{array}$} & \multicolumn{2}{|c|}{$\begin{array}{l}v\left(\mathrm{SO}_{2}\right) \\
\text { asym. }\end{array}$} & $\begin{array}{c}\mathrm{v}\left(\mathrm{SO}_{2}\right) \\
\text { sym. }\end{array}$ & $\begin{array}{l}v(\mathrm{C}-\mathrm{N}) \\
\text { imide }\end{array}$ \\
\hline 3 & 3101 & & $\begin{array}{l}1743 \\
1720 \\
\end{array}$ & \multicolumn{2}{|c|}{1585} & \multicolumn{2}{|c|}{1365} & 1188 & 1300 \\
\hline $\begin{array}{c}\text { Comp. } \\
\text { No. }\end{array}$ & \multicolumn{2}{|c|}{$v(C=0)$ imide } & \multicolumn{2}{|c|}{$\begin{array}{l}v(\mathrm{C}=\mathrm{O}) \\
\text { ketone }\end{array}$} & \multicolumn{2}{|c|}{$\begin{array}{c}v(\mathrm{C}=\mathrm{C}) \\
\text { aromatic }\end{array}$} & \multicolumn{2}{|c|}{$v\left(\mathbf{S O}_{2}\right)$ asym. } & $v\left(\mathrm{SO}_{2}\right) \mathrm{sym}$. \\
\hline 4 & $\begin{array}{l}1739 \\
1720 \\
\end{array}$ & \multicolumn{3}{|c|}{1674} & \multicolumn{2}{|c|}{1593} & \multicolumn{2}{|c|}{1361} & 1176 \\
\hline
\end{tabular}

Table (4): FTIR spectral data of compounds (5-11)

\begin{tabular}{|c|c|c|c|c|c|c|c|c|c|}
\hline \multirow[b]{2}{*}{$\begin{array}{c}\text { Comp. } \\
\text { No. }\end{array}$} & \multirow[b]{2}{*}{ Compound structure } & \multicolumn{8}{|c|}{ FTIR spectral data $\mathrm{cm}^{-1}$} \\
\hline & & $\begin{array}{c}v(\mathrm{C}-\mathrm{H}) \\
\text { aromatic }\end{array}$ & $\begin{array}{c}v(\mathrm{C}=\mathbf{0}) \\
\text { imide }\end{array}$ & $\begin{array}{l}v(C=N) \\
\text { imine }\end{array}$ & $\begin{array}{c}v(\mathrm{C}=\mathrm{C}) \\
\text { aromatic }\end{array}$ & $\begin{array}{l}v\left(\mathbf{S O}_{2}\right) \\
\text { asym. }\end{array}$ & $\begin{array}{c}v\left(\mathbf{S O}_{2}\right) \\
\text { sym. }\end{array}$ & $\begin{array}{c}v(\mathbf{C}- \\
\text { N) } \\
\text { imide }\end{array}$ & Others \\
\hline 5 & & 3109 & $\begin{array}{l}1739 \\
1720\end{array}$ & 1685 & 1593 & 1373 & 1180 & 1300 & - \\
\hline 6 & & 3062 & $\begin{array}{l}1740 \\
1720\end{array}$ & 1685 & 1593 & 1373 & 1176 & 1296 & - \\
\hline 7 & & 3100 & $\begin{array}{l}1743 \\
1722\end{array}$ & 1683 & 1593 & 1385 & 1182 & 1300 & $\begin{array}{c}\mathbf{v}\left(\mathbf{N O}_{2}\right) \\
1496 \\
1355\end{array}$ \\
\hline 8 & & 3100 & $\begin{array}{l}1739 \\
1726\end{array}$ & 1687 & 1593 & 1369 & 1182 & 1355 & $\begin{array}{c}\boldsymbol{v}(\mathbf{C}- \\
\text { Cl) } \\
1078\end{array}$ \\
\hline 9 & & 3109 & $\begin{array}{l}1743 \\
1720\end{array}$ & 1685 & 1593 & 1373 & 1199 & 1300 & - \\
\hline
\end{tabular}




\begin{tabular}{|c|c|c|c|c|c|c|c|c|c|}
\hline \multirow[b]{2}{*}{$\begin{array}{c}\text { Comp. } \\
\text { No. }\end{array}$} & \multirow[b]{2}{*}{ Compound structure } & \multicolumn{8}{|c|}{ FTIR spectral data $\mathrm{cm}^{-1}$} \\
\hline & & $\begin{array}{c}v(\mathrm{C}-\mathrm{H}) \\
\text { aromatic }\end{array}$ & $\begin{array}{c}v(C=0) \\
\text { imide }\end{array}$ & $\begin{array}{c}v(\mathbf{C}=\mathbf{N}) \\
\text { imine }\end{array}$ & $\begin{array}{c}v(\mathrm{C}=\mathrm{C}) \\
\text { aromatic }\end{array}$ & $\begin{array}{l}v\left(\mathbf{S O}_{2}\right) \\
\text { asym. }\end{array}$ & $\begin{array}{c}v\left(\mathbf{S O}_{2}\right) \\
\text { sym. }\end{array}$ & $\begin{array}{c}v(\mathrm{C}- \\
\mathrm{N}) \\
\text { imide }\end{array}$ & Others \\
\hline 10 & & 3080 & $\begin{array}{l}1725 \\
1710\end{array}$ & 1690 & 1593 & 1372 & 1185 & 1300 & $\begin{array}{c}\mathbf{v}\left(\mathrm{NO}_{2}\right) \\
1490 \\
1350 \\
\mathbf{v}(\mathrm{C}- \\
\mathbf{C l}) \\
1090\end{array}$ \\
\hline 11 & & 3109 & $\begin{array}{l}1737 \\
1720\end{array}$ & 1685 & 1593 & 1373 & 1199 & 1300 & $\begin{array}{c}\boldsymbol{v}(\mathbf{C}-\mathbf{S}) \\
609\end{array}$ \\
\hline
\end{tabular}

Table (5): Antimicrobial activity of compounds (5-11)

\begin{tabular}{|c|c|c|c|}
\hline \multirow{2}{*}{$\begin{array}{c}\text { Comp. } \\
\text { No. }\end{array}$} & Gram positive bacteria & $\begin{array}{c}\text { Gram negative } \\
\text { bacteria }\end{array}$ & $\begin{array}{c}\text { Candida } \\
\text { albicans fungi }\end{array}$ \\
\cline { 2 - 3 } & Staphylococcus aureus & Escherichia Coli & ++ \\
\hline 5 & +++ & +++ & + \\
\hline 6 & +++ & ++ & ++ \\
\hline 7 & ++ & +++ & + \\
\hline 8 & ++ & +++ & + \\
\hline 9 & +++ & ++ & ++ \\
\hline 10 & ++ & +++ & +++ \\
\hline 11 & ++++ & ++++ & + \\
\hline
\end{tabular}

Key to symbols: slightly active $=(+)=$ inhibatiotion zone $6-9 \mathrm{~mm}$

Moderately active $=(++)=$ inhibition zone $9-12 \mathrm{~mm}$

Highly active $=(+++)$ inhibition zone $13-17 \mathrm{~mm}$

Very high activity $=(++++)$ inhibition zone $>17 \mathrm{~mm}$

\section{References:}

1-Jarrahpour, A.A., Motamedifar, M., Pakshir, K., Hadi, N. and Zarei, M. 2004. Synthesis of novel azo Schiff base and their antibacterial and antifungal activities, Molecules. 9:815-824.

2-Satyanarayana, V.S.V., Sreevani, P., Sivakumar, A. and Vijayakumar, V. 2008. Synthesis and antimicrobial activity of new Schiff bases containing coumarin moiety and their spectral characterization, ARkivoc. xvii:221-233.

3-Abdel-Salam, F.H. 2010. Synthesis, biological study and complextion behavior of anionic Schiff base amphiphiles, J. Surfact. Deterg. 13:423-431.

4-Sathe, B.S., Jayachandran, E. and Jagtap, V.A. 2011. Antithelmintic activity of newly synthesized moieties of fluorobenzothiazole Schiff base, Res. J. Pharm. Bio. and Chem. Sci. 2:510-515.

5-Hussein, E.M. 2012. Synthesis of new Schiff bases and nucleoside analogues derivatives derived from D-glucose and their biological activity study, Kerbala, J. Pharm. Sci. 3:246-259.

6-Sahu, S.K., Mishra, S.K., Mandal, S. and Choudhury P. 2006. Synthesis and biological evaluation of 3-(phthalimidoethyl)-4substituted cinnamoyl substituted benzanilides, J. Indian, Chem. Soc. 83:832-834.

7-Mahapatra S.P., Ghode P., Jain D.K. and Chatuvedi S.C. 2010. Synthesis and hypoglycemic activity of some phthalimide 
derivatives, J. Pharm. Sci. and Res. 2(9):567-578.

8-Jain L. 2010. Synthesis, characterization and antibacterial activity of N-(N-acetic acid-ylphthalimide-5-yl)maleamic acid dihydrate, J. Chem. Crystallyogr. 40:428-431.

9-Malgorzata W. and Katarzyna K. 2009. Synthesis and anticonvulsant evaluation of some $\mathrm{N}$-substituted phthalimides, Acta Poloniae Pharm. 66(3):249-257.

10-Vamecg J., Bac P., Herrenknecht C. and Maurois P. 2000. Synthesis and anticonvulsant and neurotoxic properties of substituted N-phenyl derivatives of the phthalimide pharmacophore, J. Med. Chem. 43:1311-1319.

11-Sano H., Noguchi T., Tanatani A., Miyachi H., and Hashimoto Y. 2004. N-phenylphthalimide-type cyclooxygenase inhibitors derived from thalidomide, Chem. Pharm. Bull. 52:1021-1022.
12-Wan Chai P., Sirichai A., Sirintorn Y., and Warinthorn C. 2007. Synthesis of N-phenyl phthalimide derivatives as $\alpha$-Glucosidase inhibitors, Arch. Pharm. Res. 30(12):1501-1506.

13-Al-Azzawi A.M. and Ali M. S. 2007. Modification of phthalimidyl phenol-formaldehyde resins via esterification, J. AlNahrain Univ. Sci. 10(1):38-45.

14-Al-Azzawi A.M. and Mehdi S.A. 2010. Synthesis, characterization and biological activity study of $\mathrm{N}$ sulfonamido maleimides substituted with heterocycles, Baghdad Sci. J. 7(1):641-653.

15-Abd Al-Razzak, M. S. 2012. M.Sc. Thesis, Chem. Dept. College of Sci., Baghdad University.

16-Silverstein, R.M. and Bassler, G.C. 1981. Spectrometric identification of organic compounds, $4^{\text {th }}$ Ed., John Wiley and Sons. New York.

\footnotetext{
تحضير وتثخيص ودراسة الفعالية المضادة للمايكروبات لقواعد شيف جديدة

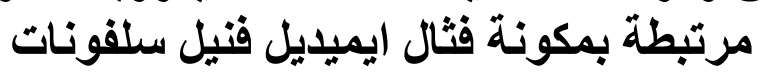
مروة شوقي عبل الرزاقث

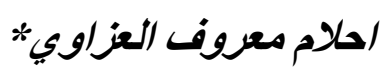

*قنم الكيمياء / كلية العلوم / جامعة بغدادي"

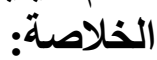

تم في هذا البحث تحضير عدد من قواعد شيف الجديدة المرتبطة بمكونـة فنال ايميديل فنبل سلفونات بو اسطة التحضير التتعدد الخطوات.

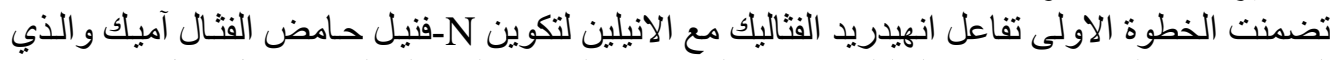

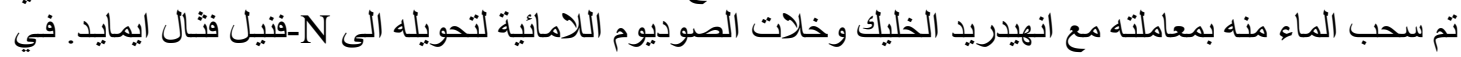

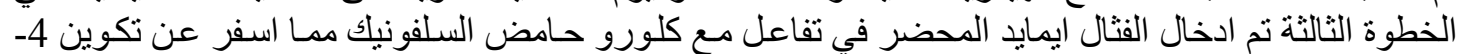
الفيل (-N)

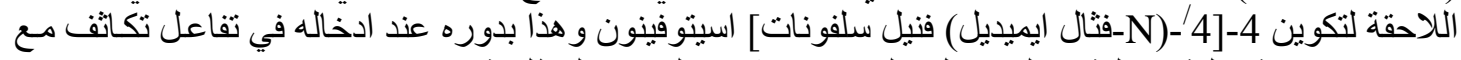

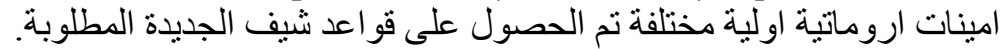

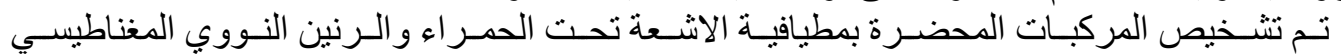
من من الفطريات وقد اوضحت النتائج بانها ذات فعالية جيدة ضد البذائ المايكروبات قيد الدراسة.
} 